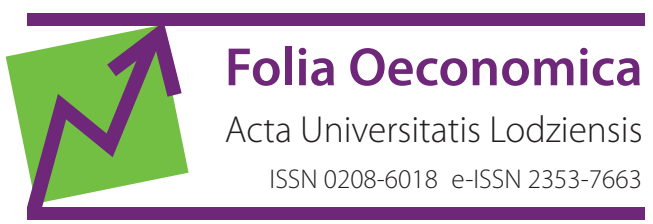

www.czasopisma.uni.lodz.pl/foe/

2(353) 2021

DOI: https://doi.org/10.18778/0208-6018.353.01

\title{
Agnieszka Palma
}

University of Łódź, Faculty of Economics and Sociology, Department of Demography and Social

Gerontology, Łódź, Poland, agnieszka.palma@uni.lodz.pl

\section{Fertility Trends in European Countries}

\begin{abstract}
This work is intended as an attempt to illustrate and compare the pattern of fertility in European countries: Belarus, Croatia, Hungary, Poland, Portugal, Spain, Sweden, and Switzerland. It deals with the analysis of fertility trends, with an emphasis on birth by parity. Using data from the Human Fertility Database (HFD) from the year 2016, it has considered the parameters of parity progression ratios (PPR), projected parity progression ratios (PPPR), age-specific fertility rates (ASFR), age-order specific fertility rates (AOSFR), and cumulated order-specific fertility rates accordingly analysed. We have applied indicators known as the projected parity progression ratios to estimate trends of fertility. These offer a more detailed view of the family formation process than the traditional total fertility rate (TFR).
\end{abstract}

Keywords: fertility rates, average parity, parity progression ratios, projected parity progression ratios JEL: J11, J12, J13 


\section{Introduction}

Fertility analysis is a crucial subject in demography and it has attracted the attention of many researchers. Demographers have designed many various methods to measure this phenomenon. Most studies have used common measures, such as age-specific fertility and total fertility rates, to analyse fertility trends. These measures provide aggregated estimates of fertility. They do not provide enough detail on exactly how fertility is changing within parity. The analysis of fertility by parity helps us understand the fertility transition in a given population.

Parity progression ratios (PPRs) have been one of the most frequently used demographic tools in analysing data by parity. Parity progression ratios are well described in the demographic literature (Preston, Heuveline, Guillot, 2001). Louis Henry (1980) was the first to introduce parity progression ratios in 1953. They were further refined by other authors: Rodriguez and Hobcraft (1980), Brass and Juarez (1983), Feeney (1983), Brass (1985), Yadava and Bhattacharya (1985), Feeney and Jingyuan (1987), Aoun and Airey (1988), Yadava, Pandey, and Saxena (1992), Sloggett et al. (1994), Islam and Yadava (1997), Bhardwaj, Sharma, and Kumar (2010), as well as Yadava and Kumar (2011). By definition, a parity progression ratio refers to the proportion of women who progress from parity $i$ to $i+1$ (Feeney, Jingyuan, 1987; Preston, Guillot, Heuveline, 2001). PPRs can be calculated on a cohort or period basis depending on the data available.

Frejka (2008) wrote that the decreasing PPR for first and second births played a key role in the fertility decline of European women born after 1955. In Central and Eastern Europe, the fertility decline was mainly caused by the decreasing PPR for second births. Kohler, Billari, and Ortega (2002) and Billari and Kohler (2004) suggest that the lowest fertility in Europe in the 1990s was the result of delayed childbearing, especially for first births, as well as a low probability of progression after the first child.

Brass (1985) described a method of using the current distribution of age-order specific fertility rates to estimate the future trends of parity progression ratios known as the projected parity progression ratio method. PPPRs denote the proportions of women who are expected to progress from parity $i$ to parity $i+1$ by the end of their childbearing years. This study is based on this method. Brass used it in the Seychelles, and was subsequently applied by Moultrie et al. (2013) in Cambodia, and by Rossa and Palma (2020) in Poland, with some improvements.

The main purpose of this study is to investigate the tempo and pattern of fertility in European countries and the parity progression schedule. The specific objectives are to estimate parity progression ratios for each parity and to examine the differentials in these ratios in the considered countries. Taking into account the fact that there are very few women with high birth order, and therefore no signif- 
icant changes in the distribution of children in the family, we focused on parities from one to four for simplification.

In this paper, we also make some ex-post comparisons, i.e. between the observed and predicted PPR for women in different age groups and between the PPPR and completed PPR observed for women aged 49 and over in a given calendar year. They allow us to assess the prediction accuracy of the modified Brass method as well as to explain future changes in the distribution of parities over a ten-year time horizon.

Input data were sourced from the Human Fertility Database. They present age-parity exposure of the female population in the year 2016 as well as counts of live births by birth order and age of mothers in the same year. The choice of countries was dictated by TFR size, data availability and geographical location. The database is available online at www.humanfertility.org.

\section{Model for estimating parity progression ratios}

\subsection{Notation}

For the convenience of the reader, we repeat the relevant material (Moultrie et al., 2013), thus making our exposition self-contained.

Let us assume the following notation:

$N_{x}$-population exposure for females in one-year age interval $[x, x+1)$,

$N_{x}(i)$ - population exposure for females in one-year age interval $[x, x+1)$ and

of parity $i$,

$N$ - total female population exposure in the reference year,

$N(i)$ - total population exposure in the reference year for women of parity $i$.

The following relations hold:

$$
N_{x}=\sum_{i=0}^{\pi} N_{x}(i), \quad N(i)=\sum_{x=\alpha}^{\beta} N_{x}(i), \quad N=\sum_{i=1}^{\pi} N(i)=\sum_{x=\alpha}^{\beta} N_{x},
$$

where $\pi$ is the highest parity in the data set, and $\alpha, \beta$ define the limits of the reproductive age range $[\alpha, \beta+1)$. Further, we will assume that $\alpha=15$ and $\beta=49$.

Let us also denote:

$B_{x}$ - the number of births to women aged $[x, x+1)$,

$B_{x}(i)$ - the number of births to women in one-year age interval $[x, x+1)$ and of parity $i$,

$B$ - the total number of births in the reference year,

$B(i)$ - the total number of births in the reference year to women of $i$-th parity.

Similarly as in (1), we obtain the following relations: 


$$
B_{x}=\sum_{i=0}^{\pi} B_{x}(i), B(i)=\sum_{x=\alpha}^{\beta} B_{x}(i), B=\sum_{i=1}^{\pi} B(i)=\sum_{x=\alpha}^{\beta} B_{x} .
$$

Now we define the Age-Specific Fertility Rate (ASFR) and the Age-Order Specific Fertility Rate (AOSFR) for women at the age between $x$ and $x+1$ :

$$
A \operatorname{ASF} R_{x}=\frac{B_{x}}{N_{x}} \text { and } \operatorname{AOSFR}_{x}(i)=\frac{B_{x}(i)}{N_{x}} .
$$

Observe that:

$$
A S F R=\sum_{i=1}^{\pi} \operatorname{AOSFR}_{x}(i)
$$

The Total Fertility Rate (TFR) and the Total Order Fertility Rates (TOFR's) are defined as:

$$
\operatorname{TFR}=\sum_{x=\alpha}^{\beta} A \operatorname{SFR} R_{x} \text { and } \operatorname{TOFR}(i)=\sum_{x=\alpha}^{\beta} \operatorname{AOSFR} R_{x}(i) .
$$

The Cumulated Age-Order Fertility Rates for parity $i$ are derived by summing age-order specific fertility rates up to the desired age $y$. Thus, we have:

$$
\operatorname{TOFR}_{y}(i)=\sum_{x=\alpha}^{y} A O S F R_{x}(i) .
$$

Average parity $P$ in the population is calculated by dividing the total number of children ever born by the number of women $N$ :

$$
P=\frac{1}{N} \sum_{j=0}^{\pi} j \cdot N(j) .
$$

Now, let $W(i)$ be the number of women in the population having attained parity $i$ or higher. Note that:

$$
W(i)=\sum_{j=i}^{\pi} N(j)
$$

Then the proportion $M(i)$ of women ever-attaining parity $i$, can be expressed as:

$$
M(i)=\frac{W(i)}{N} .
$$


Obviously, the corresponding proportion at parity zero and over is $M(0)=N / N=1$.

By analogy, we obtain $W_{x}(i)$ and $M_{x}(i)$.

It can be shown that the average parity (7) can be written as follows:

$$
P=\frac{1}{N} \sum_{j=1}^{\pi} W(j)=\sum_{j=1}^{\pi} M(j) .
$$

\section{2. (Projected) Parity Progression Ratios}

Now we can derive the proportions of women who have progressed from parity $i$ to $i+1$, which are the parity progression ratios. These are obtained by dividing the proportion of women with $i+1$ children by that with $i$ children. Thus the parity progression ratios $P P R(i)$ and $P P R_{x}(i)$ are given by:

$$
\operatorname{PPR}(i)=\frac{M(i+1)}{M(i)}, \operatorname{PPR}_{x}(i)=\frac{M_{x}(i+1)}{M_{x}(i)} .
$$

It is important to know that age-specific parity progression ratios $P P R_{x}(i)$ calculated for young women who have not yet completed their childbearing life should be treated as current age-specific PPRs. These ratios can change rapidly when women move into higher parities in the future. In such cases, it is reasonable to calculate projected parity progression ratios to predict parity progression of young women by the end of their childbearing age.

Observe that proportions (9) can be expressed in terms of respective parity progression ratios (11) for lower birth orders as follows:

$$
M(i+1)=P P R(i) \cdot M(i)=P P R(i) \cdot P P R(i-1) \cdot P P R(i-2) \ldots P P R(0) .
$$

Projected proportions attaining parity $i, M_{x}^{*}$ denote the proportions of women who are expected to attain at least parity $i$ by the end of their childbearing life,

$$
M_{x}^{*}(i)=M_{x}(i)+\operatorname{TOFR}(i)-\operatorname{TOFR}_{x}(i),
$$

where the difference between Total Order Fertility Rate TOFR(i) given in (5) and Cumulated Age-Order Fertility Rate $\operatorname{TOFR}_{x}(i)$ defined in (6) can be treated as an estimate of an additional proportion of women aged $x$ expected to achieve parity $i$ by the end of their childbearing years. However, this interpretation is admissible under the assumption that current fertility will remain constant until the end 
of women's reproductive life span and that in a given year women have had at most one birth (Moultrie et al., 2013: 74).

Finally, the Projected Parity Progression Ratios (PPPRs) defined for one-year age intervals are as follows:

$$
\operatorname{PPPR}_{x}(i)=\frac{M_{x}^{*}(i+1)}{M_{x}^{*}(i)} .
$$

These measures give the proportions of women who are expected to progress from parity $i$ to parity $i+1$ by the end of their childbearing years.

Two main assumptions are underlying the projected PPR method. According to Moultrie et al. (2013), women are assumed to have had at most one birth in a given year. The second assumption is that thus derived AOSFRs will remain constant in the future throughout the women's childbearing period.

\section{Comparison of fertility patterns in European countries - Analysis based on Projected Parity Progression Ratios}

\subsection{Data, calculations, graphical illustration}

Input data were sourced from the Human Fertility Database. The choice of countries was determined by TFR size, data availability, and geographical location. Data were not available for all European countries. Eight countries were selected for analysis. These are Belarus, Croatia, Hungary, Poland, Portugal, Spain, Sweden, and Switzerland. The reference year is 2016.

Period Specific Fertility Rates, Average Parity, and Total Fertility Rates

The period level of fertility is commonly measured by the total fertility rate (TFR), which gives the average number of children per woman. The global average fertility rate is just below 2.5 children per woman today. Over the last 50 years, the global fertility rate has halved.

More recently, according to the United Nations, the period total fertility rate in Europe reached 1.61 live births per woman in 2016. The lowest fertility rates were observed in Portugal (1.28 births per woman), Greece (1.31), Spain (1.32), Cyprus (1.34), Italy (1.36), and Poland (1.39). Conversely, France (1.89 births per woman) was the European country with the highest total fertility rate, followed 
by Sweden (1.87), Ireland (1.88), Russia (1.8), the United Kingdom (1.79), and Belarus (1.7).

The following figure illustrates this measure for the countries considered, Europe, and the World in 2016.

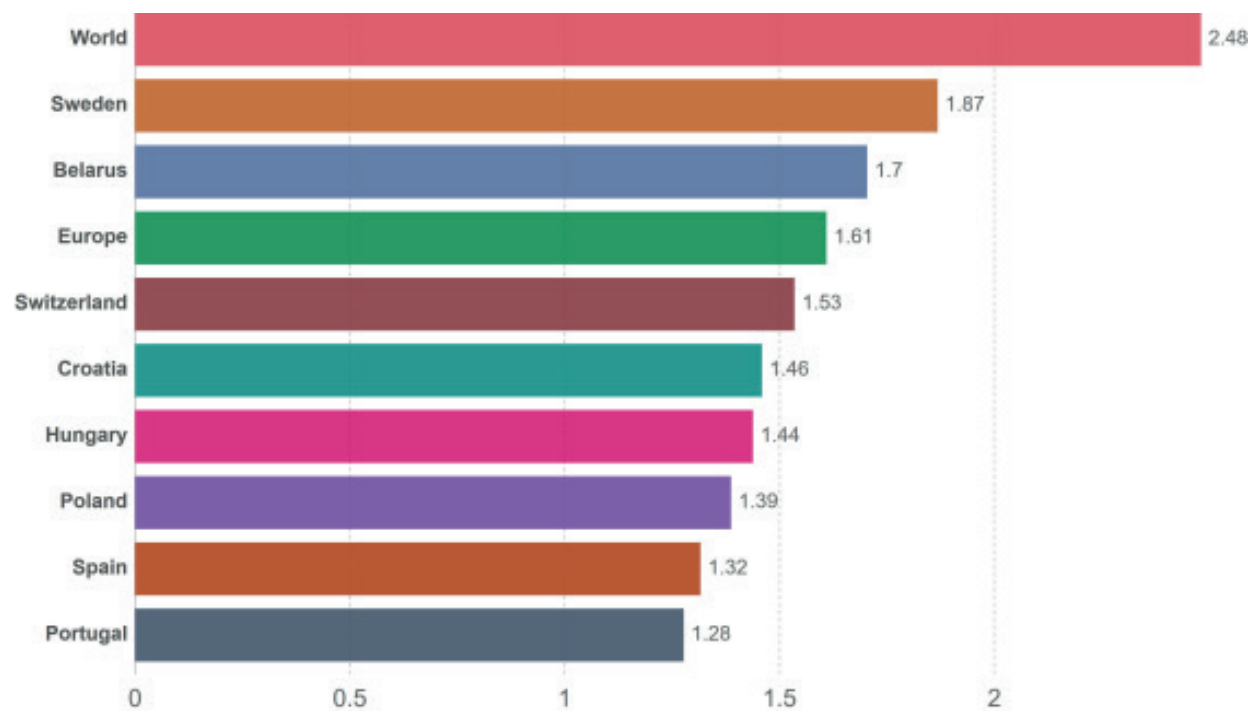

Figure 1. Total Fertility Rates in 2016

Source: Our World in Data

It is known that TFR does not give an accurate picture of the effects of fertility in family formation because it ignores the birth sequence, i.e. the fact that only women who are currently at parity zero, one, or two are at risk of having their first, second, or third child respectively. Thus, the same level of total fertility can be achieved by combining quite different distributions of birth by parity. Consequently, TFR does not inform about the influence of fertility on family formation.

In this analysis, the distribution of parities was estimated for women who had almost reached their reproductive age (40-45 years). Countries were sorted according to their TFR values. The differences in the distribution of birth parities between countries in 2016 are shown in Figure 2. It clearly illustrates the dissimilarities between countries in terms of the share of childless women as well as the varying weight of the first and the third child. 


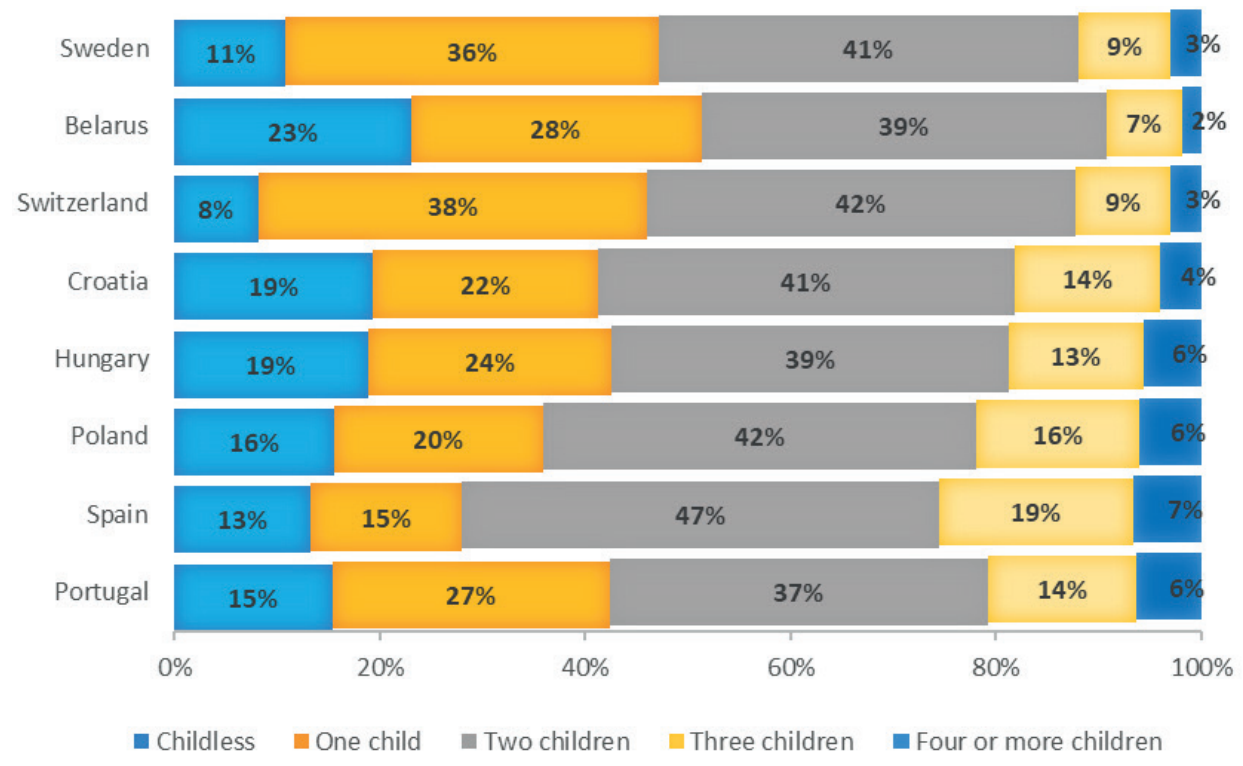

Figure 2. Women's birth parity distribution (age group 40-45) of European countries in 2016 Source: the author's own elaboration; The Human Fertility Database

Based on (3), we calculated the age-specific fertility rates $\left(A S F R_{x}\right)$ and the age-order specific fertility rates $\left(\operatorname{ASSF}_{x}(i)\right)$ for women aged between $x$ and $x+1$ and of parity $i=1,2,3,4$ for our countries. Age-specific fertility rates enable the analysis of the pattern of fertility by age of women, and the analysis of changes in the timing of childbearing. The calculation results are presented graphically below.

In Figure 3, we see that age-specific fertility rates vary greatly from one country to another. In most of the countries considered, the highest values of ASFR are attributed to older age groups. Only in Belarus, we notice a significant shift of the graph to the left, which means that in this country the highest ASFR values correspond to younger age groups. The uncharacteristic shape of the graph can be observed in Hungary, as ASFR values are higher for young women compared to those in the other analysed countries. Sweden, Belarus, and Switzerland have the highest rates, while fertility in the other countries barely reaches 0.1 , even at the peak age of fertility. 


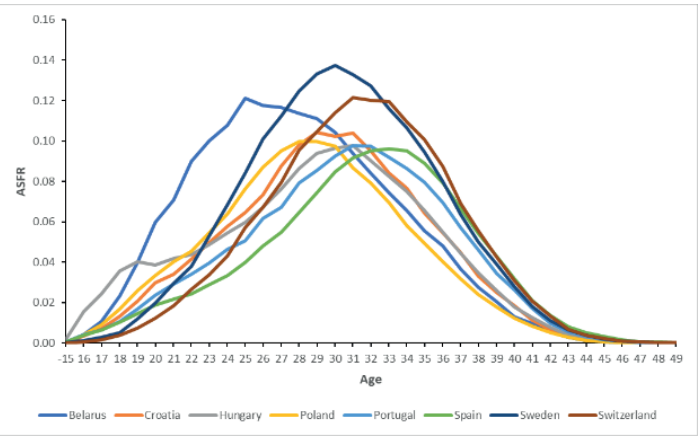

Figure 3. Age-Specific Fertility Rates, 2016

Source: the author's own elaboration; The Human Fertility Database

Then, we have a look at the $\operatorname{AOSFR}(i)$ charts for $i=1,2,3,4$. In most of the analysed countries, there is a tendency to delay the birth of children. This is different in Belarus, here the coefficients take the highest values for $i=1$, and additionally for younger women than in other countries. There is also a decrease in the number of newborn children, and in some countries, such as Spain, Poland and Portugal, this decrease is very pronounced.
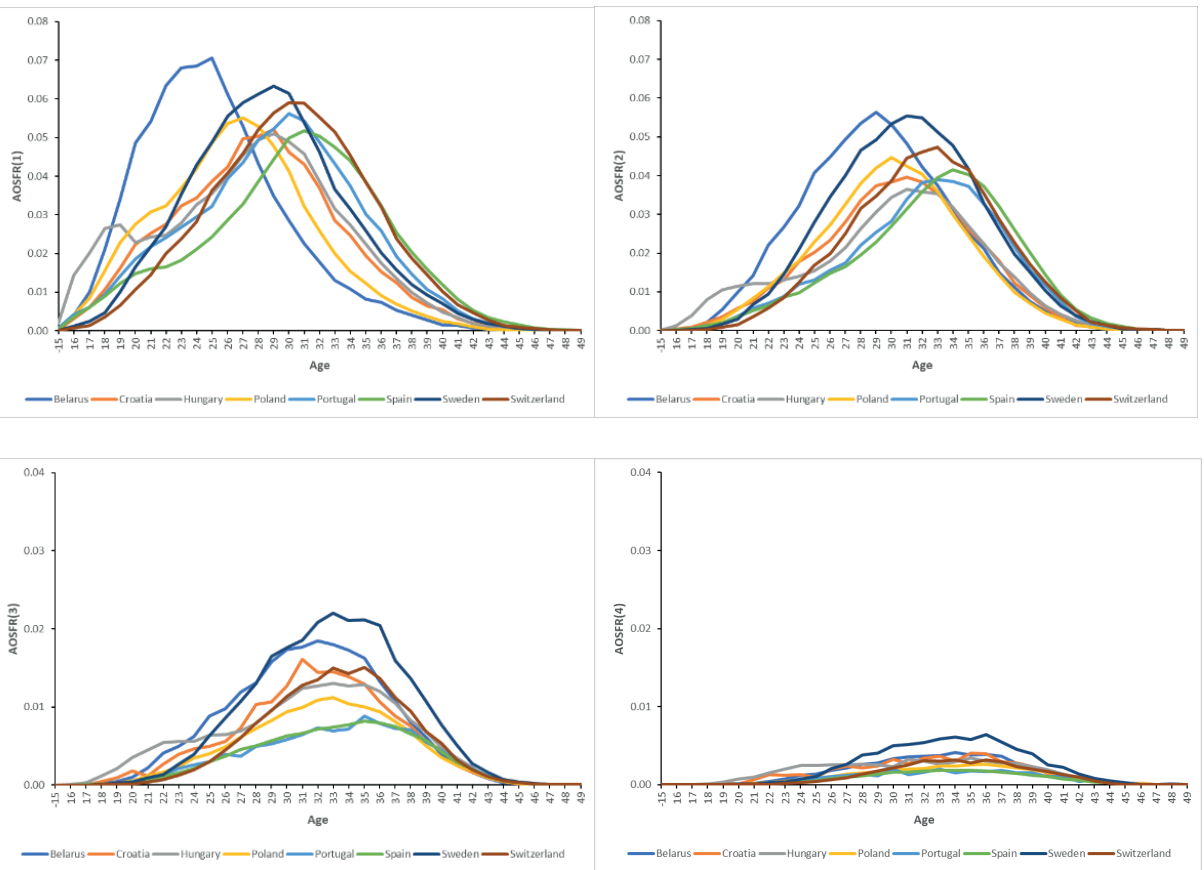

Figure 4. Age-Order Specific Fertility Rates

Source: the author's own elaboration; The Human Fertility Database 
In the next step of the analysis, we computed the average parity of women of a given age $x, P_{x}$, for eight countries. Those were calculated according to (7) on the empirical data for selected countries from 2016 by dividing the total number of children ever born to women aged $x$ in the reference year 2016 by the number of women aged $x$ that year. Parameters $P_{x}$ showed a typical pattern of average parities increasing with age, which we may see on the graph below. Compared to the countries surveyed, Spain has the lowest average parity, while Sweden has the highest. Belarus is characterised by higher values for young women.

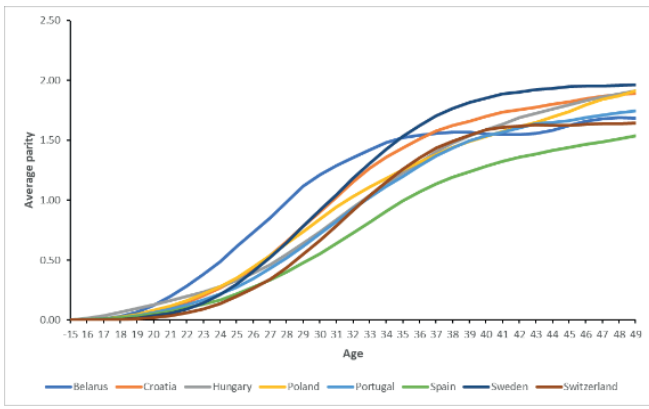

Figure 5. Average Parity, 2016

Source: the author's own elaboration; The Human Fertility Database

\section{Projected and observed parity progression ratios}

To explore parity progression ratios, we calculated proportions of women $M_{x}(i)$ aged between $x$ and $x+1$ having attained parity-order $i$ or higher using formula (9). Finally, from (11), we obtained parity progression ratios $P P R_{x}(i)$.

In the last step, we performed some additional calculations leading to projected parity progression ratios. First, cumulated age-order fertility rates $T O F R_{x}(i)$ must be computed. Next, we obtained the projected proportions of women $M_{x}^{*}(i)$ aged $[x, x+1)$ who will attain at least parity $i$ by the end of their childbearing years according to formula (13). Finally, the projected parity progression ratios between parity $i$ and $i+1$ were computed using formula (14). We will compare the projected (completed) and observed (uncompleted) PPRs by age and parity for every country considered. We present our results graphically.

In this part of the work, we will look more closely at the differences between the selected European countries by illustrating the projected and observed PPRs by age and parity. We can see typical shapes of observed (uncompleted) PPRs with curves increasing with age whereas projected PPRs tend to level. Both observed and projected PPRs decrease as parity increases. As expected, there are considerable differences between both types of PPRs, especially for young women, although differences vanish as they get older. Projected and observed parity progression ratios for $i=0,1,2,3$ are presented graphically below. 


\section{Belarus}
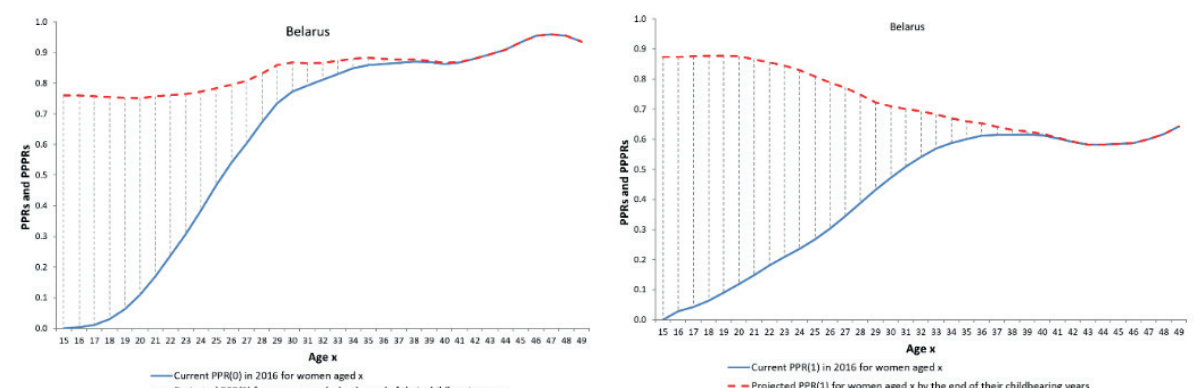

-Current PPR(0) in 2016 tor women aged $x$
- - Projected PPR (1) for women aged $x$ by the end of their childbearing vears
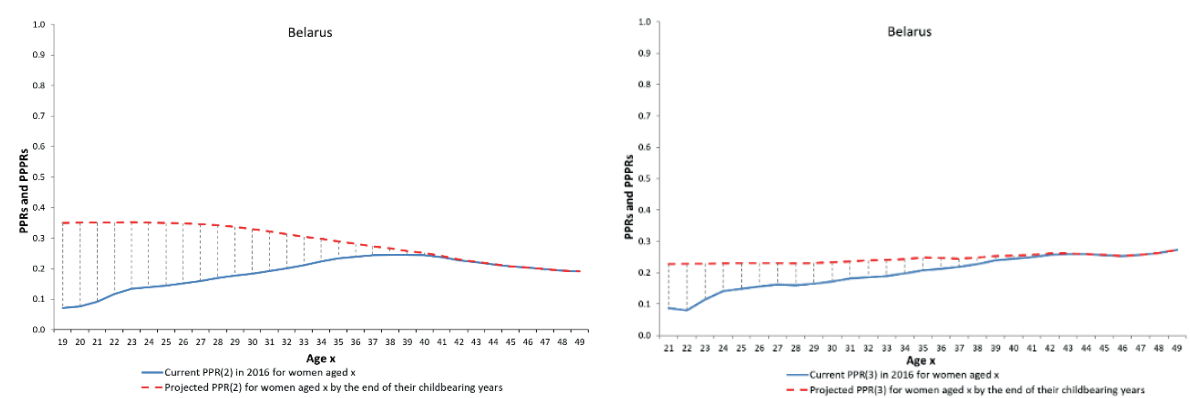

\section{Croatia}
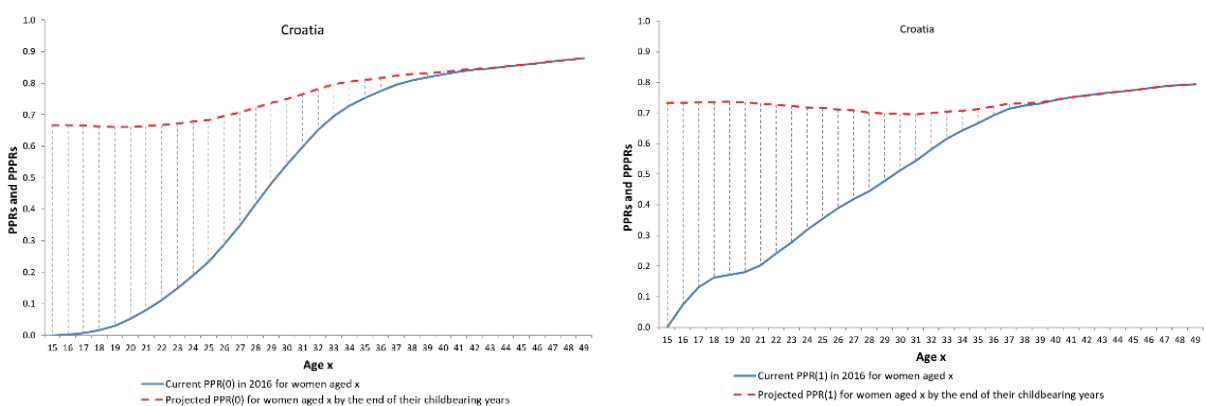

—Current PPR 1 ) in 2016 for women aged $x$

- - Projected PPR(1) for women aged $x$ by the end of their childbearing years
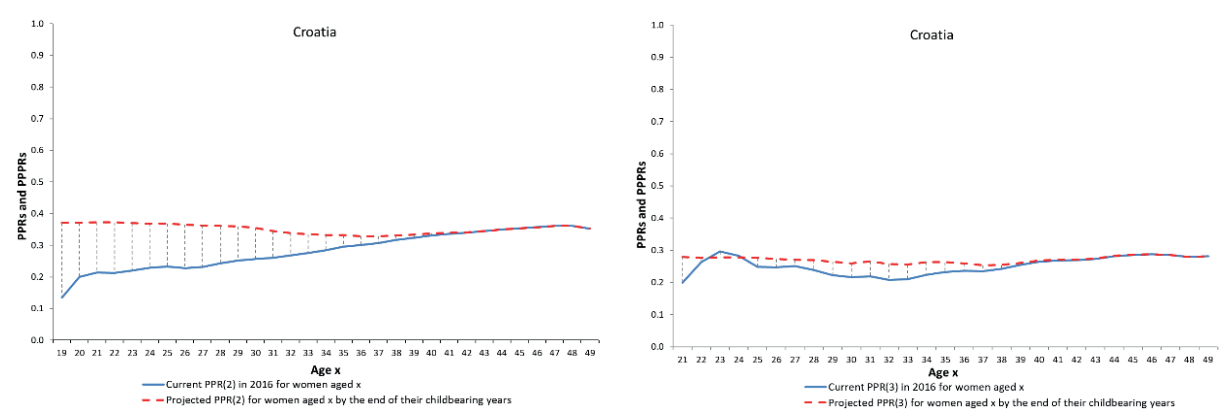


\section{Hungary}
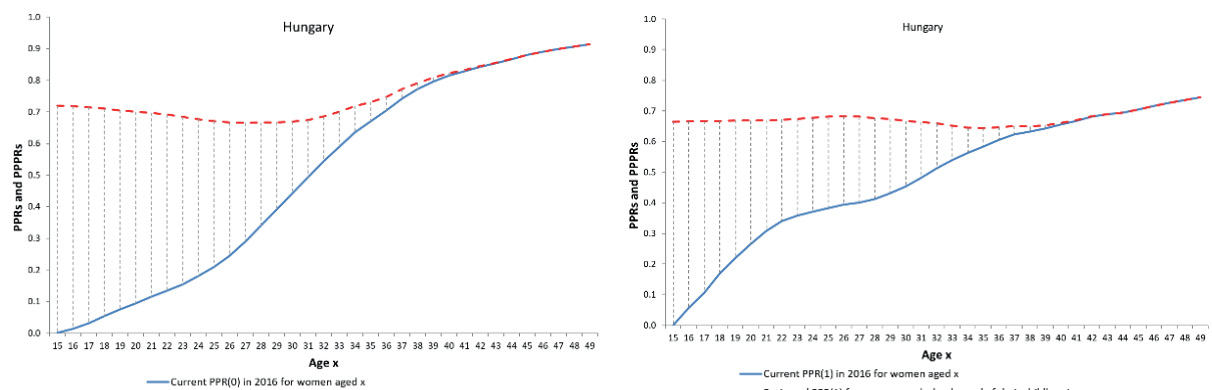
- Current PPR(0) in 2016 for women aged $x$
- - Projected PPR(0) for women aged $x$ by the end of their childbearing years

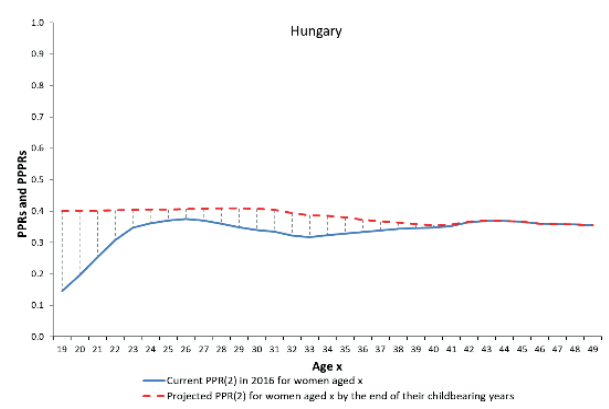




\section{Portugal}
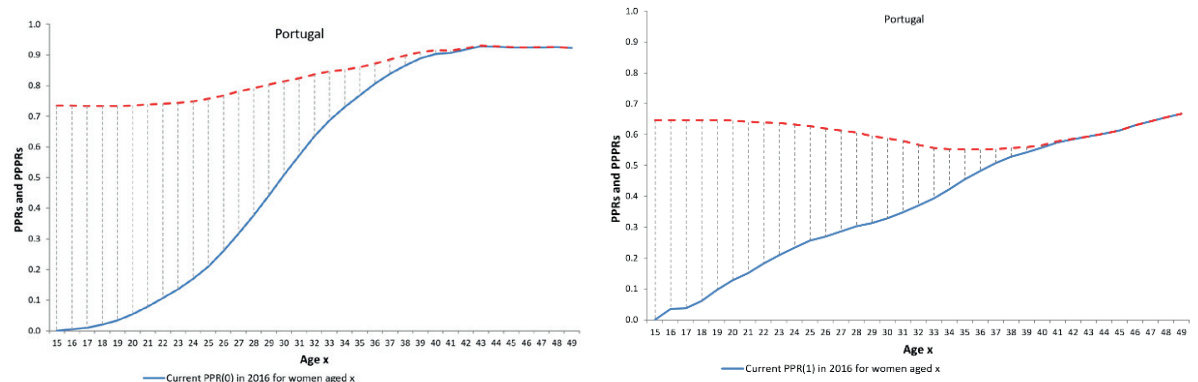

- Current $P P R(0)$ in 2016 for women aged $x$
- - Projected $P P R(0)$ tor women aged $x$ by the end of their childbearing years

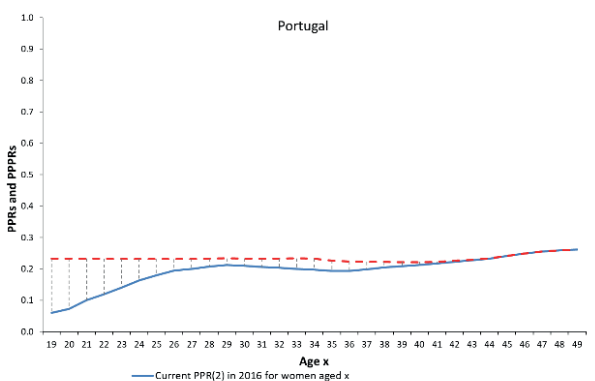

- - Projected PPR (1) for women aged $x$ by the end of thelr chlldbearing years

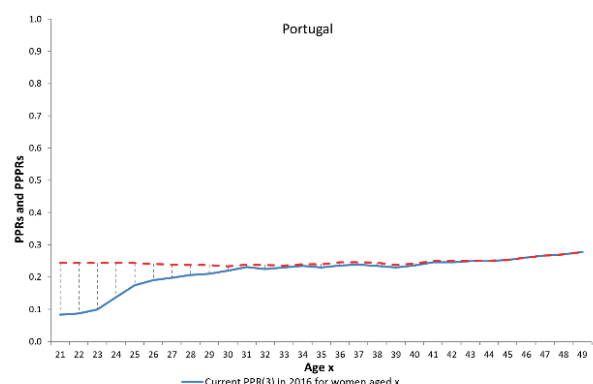

- - Projected PPR(2) for women aged $x$ by the end of their childbearing years

—Current PPR(3) in 2015 for women aged $x$

- - Projected PPR(3) for women aged $x$ by the end of their childbearing years

\section{Spain}
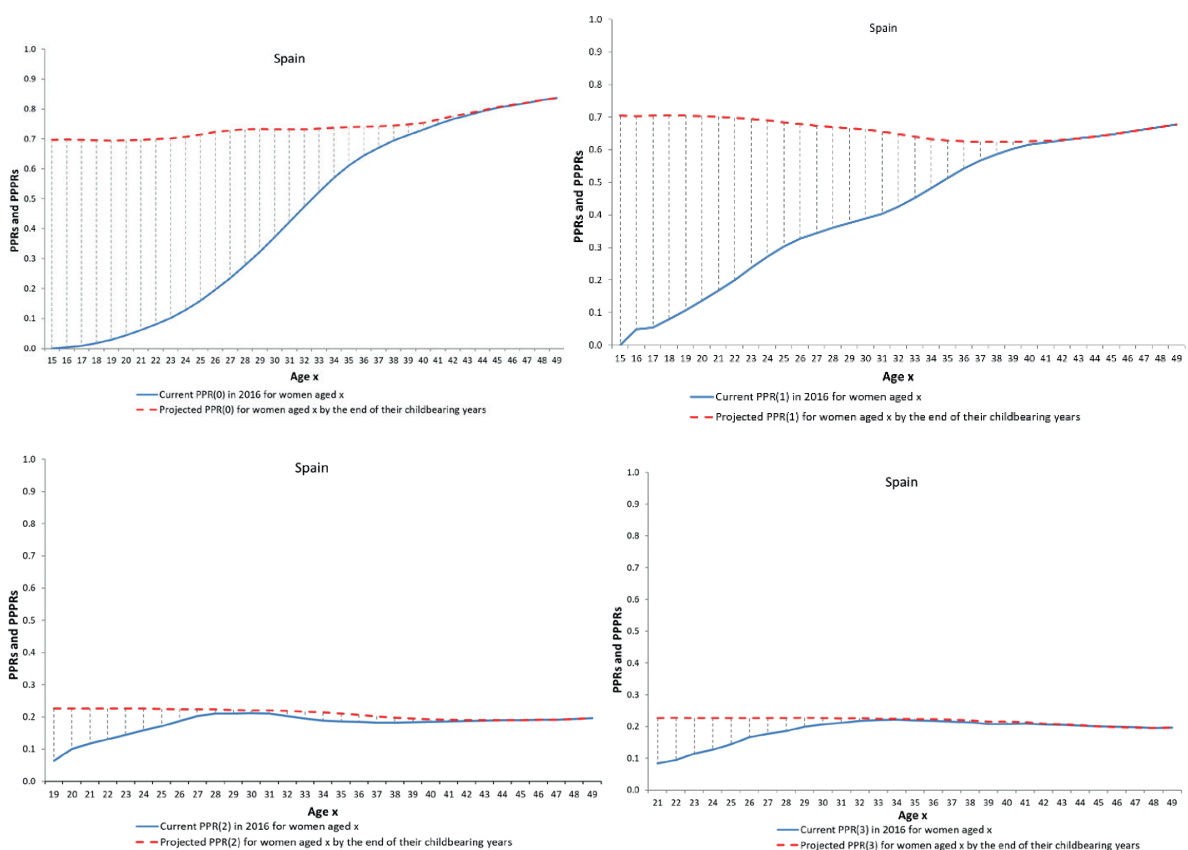


\section{Sweden}
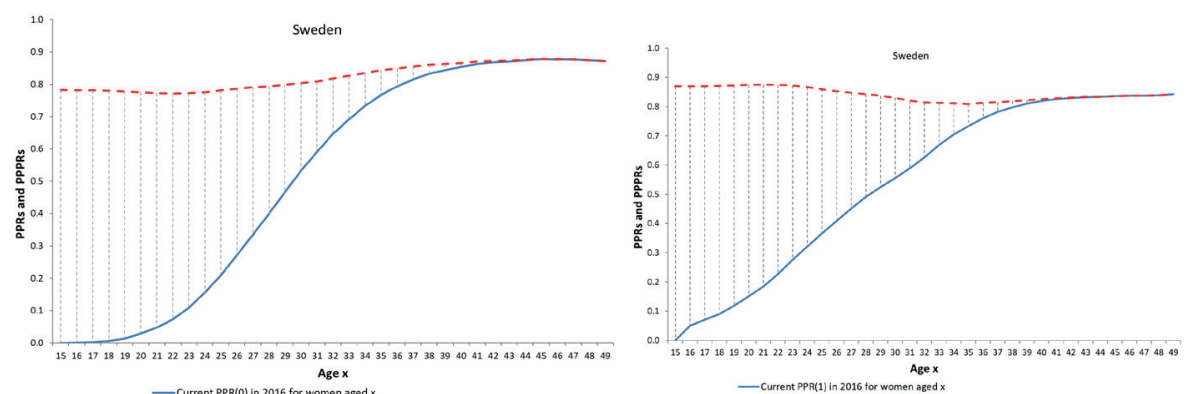

- Cin PPR(0) in 2016 for women aged

—Current PPR(1) in 2016 tor women aged $x$
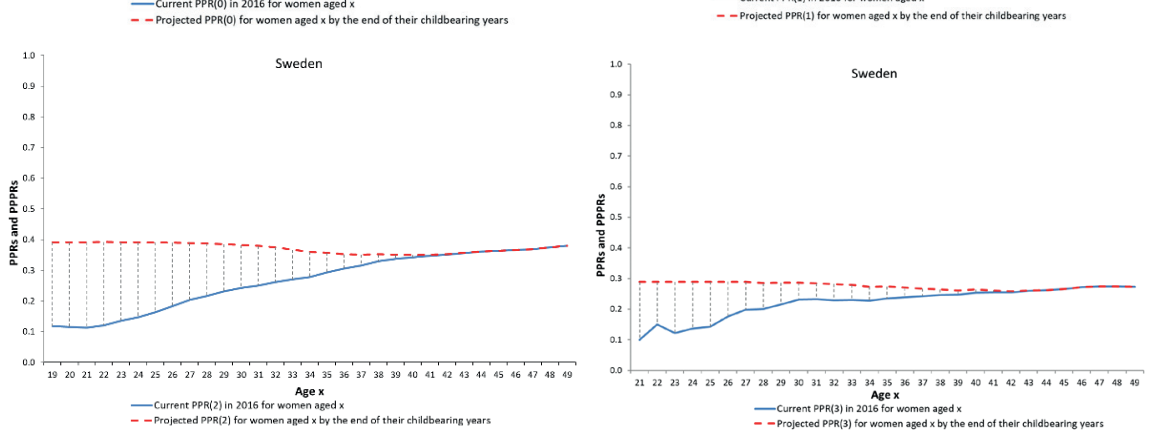

\section{Switzerland}
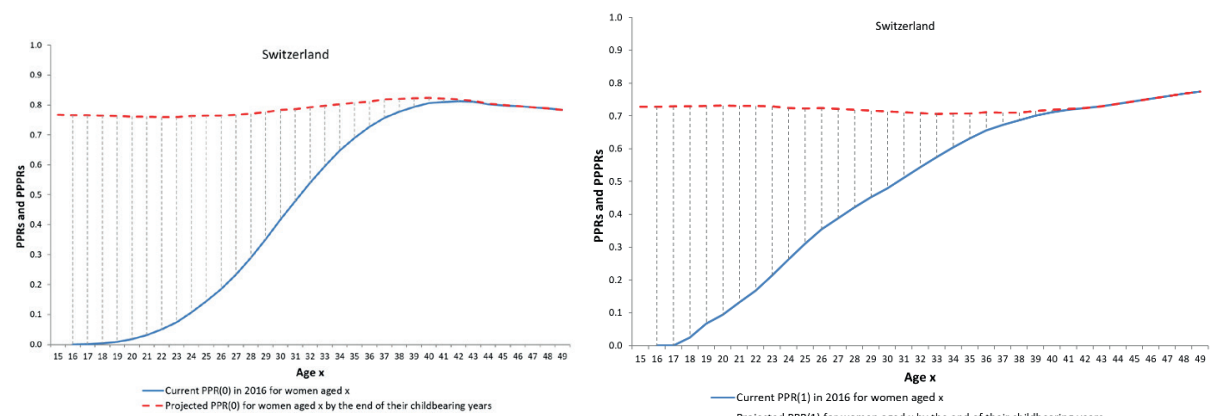

Age $x$
—Current PPR $[1]$ in 2016 for women aged $x$

- - Projected PPR(1) for women aged $x$ by the end of their childbearing years
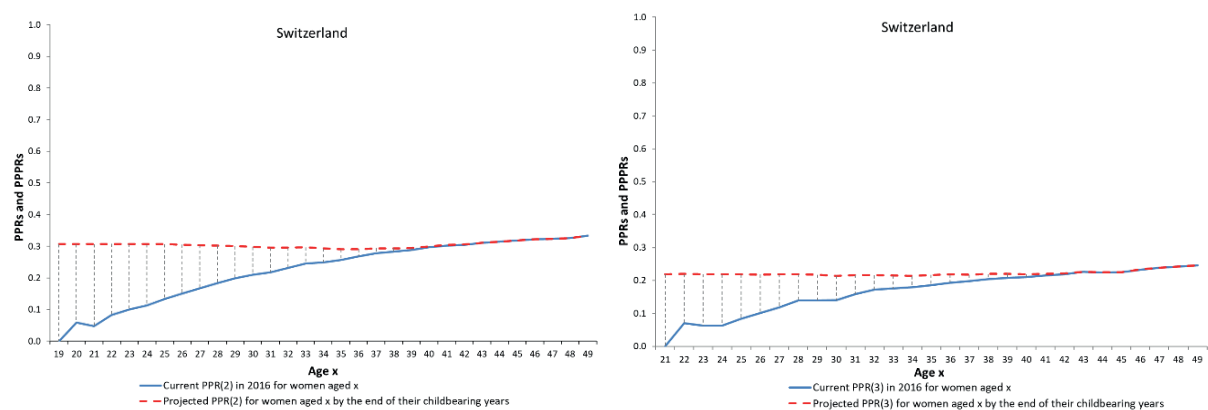

Figure 6. Projected and observed parity progression ratios

Source: the author's own elaboration; The Human Fertility Database 
Comparing the individual graphs for the countries selected, we can see how considerable the differences between the values of the projected and observed PPRs are for parities $i=0,1,2,3$, respectively.

The following figures illustrate the graphs of PPRs for all the countries considered, depending on the parity.
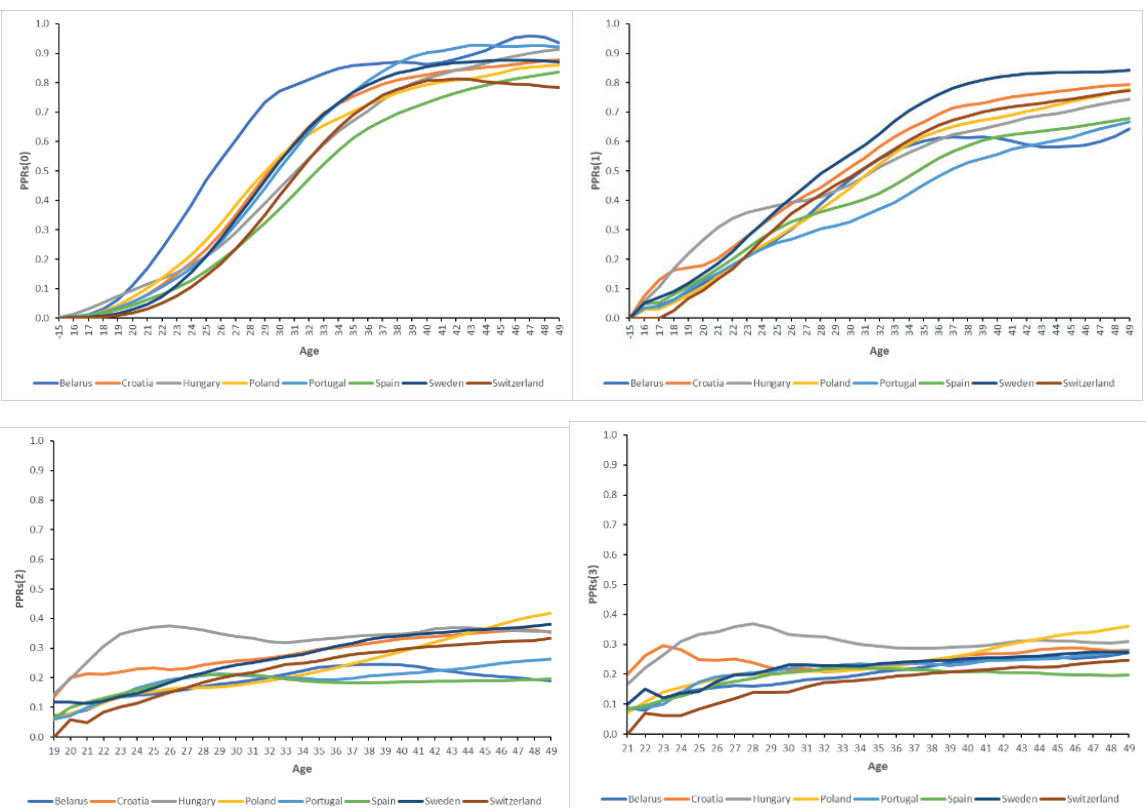

Figure 7. Parity Progression Ratios PPR $(i)$ for $i=0,1,2,3$

Source: the author's own elaboration; The Human Fertility Database

These parity progression ratios are calculated for all women. However, in this calculation, there are young women who have not yet completed their childbearing years. To obtain their parity progression ratios when they reach the end of childbearing, we need to calculate projected parity progression ratios.

\section{Prediction}

The aim of this section is to see if the projected parity progression ratios give a good prediction of the completed parity progression ratios of younger women. To do this, the parity progression ratios for younger women in 2006 were projected forwards by ten years and then compared to the observed parity progression ratios in 2016. Figure 6 shows a comparison of the projected ratios for parities $i=0,1,2,3$ (predictions based on the 2006 fertility data) with the observed completed ratios for women aged 49 in the years 2006, 2011, and 2016 for the countries concerned. Analogous comparisons are made between the projected parity progression ratios (predictions 
based on 2006 fertility data) and the observed parity progression ratios for women aged 35 and of parities $i=0,1,2,3$ in the years 2006, 2011, and 2016. We could not make this comparison for Croatia because data from 2006 are not available.

\section{Belarus}
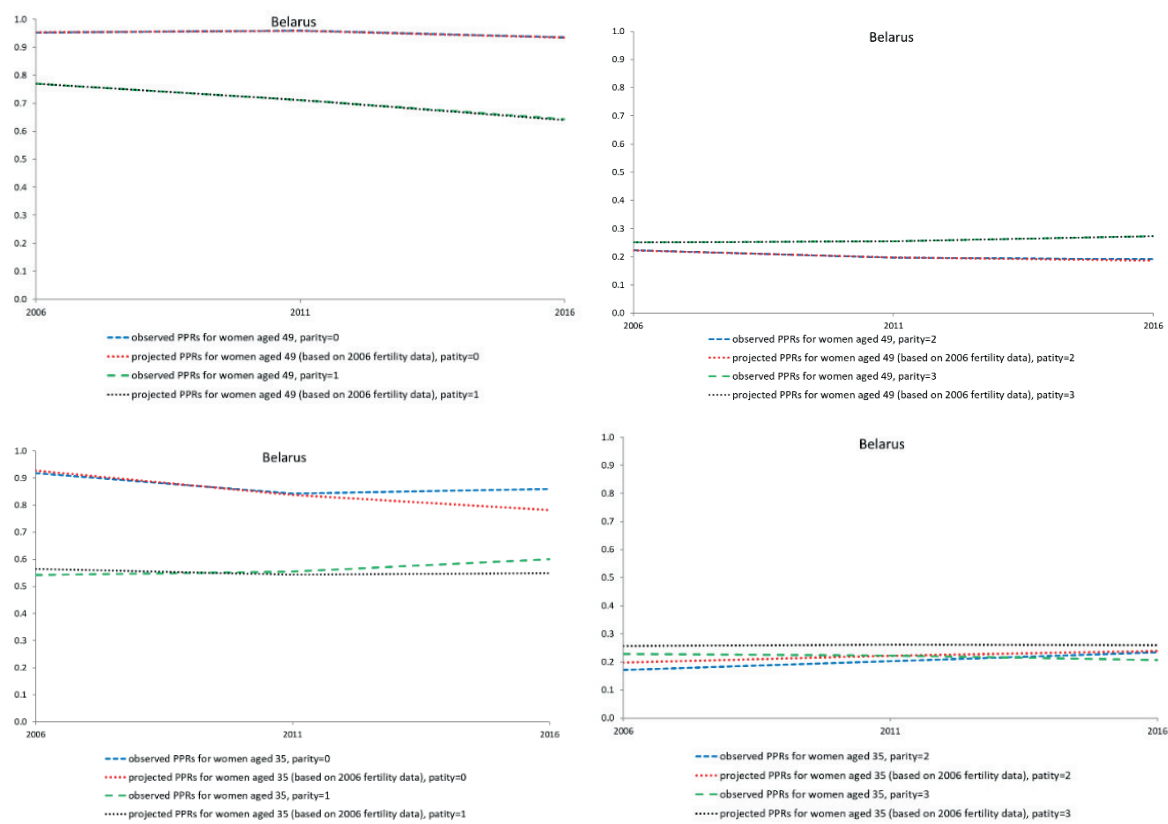

Hungary
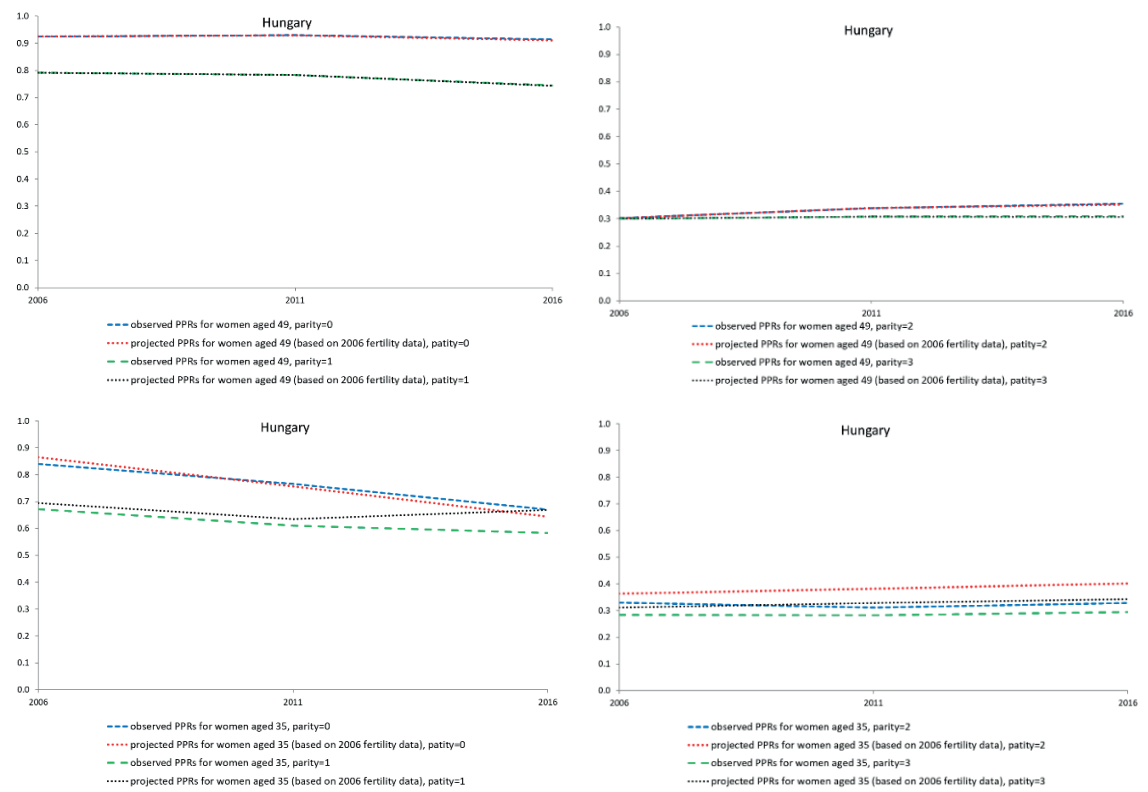


\section{Poland}
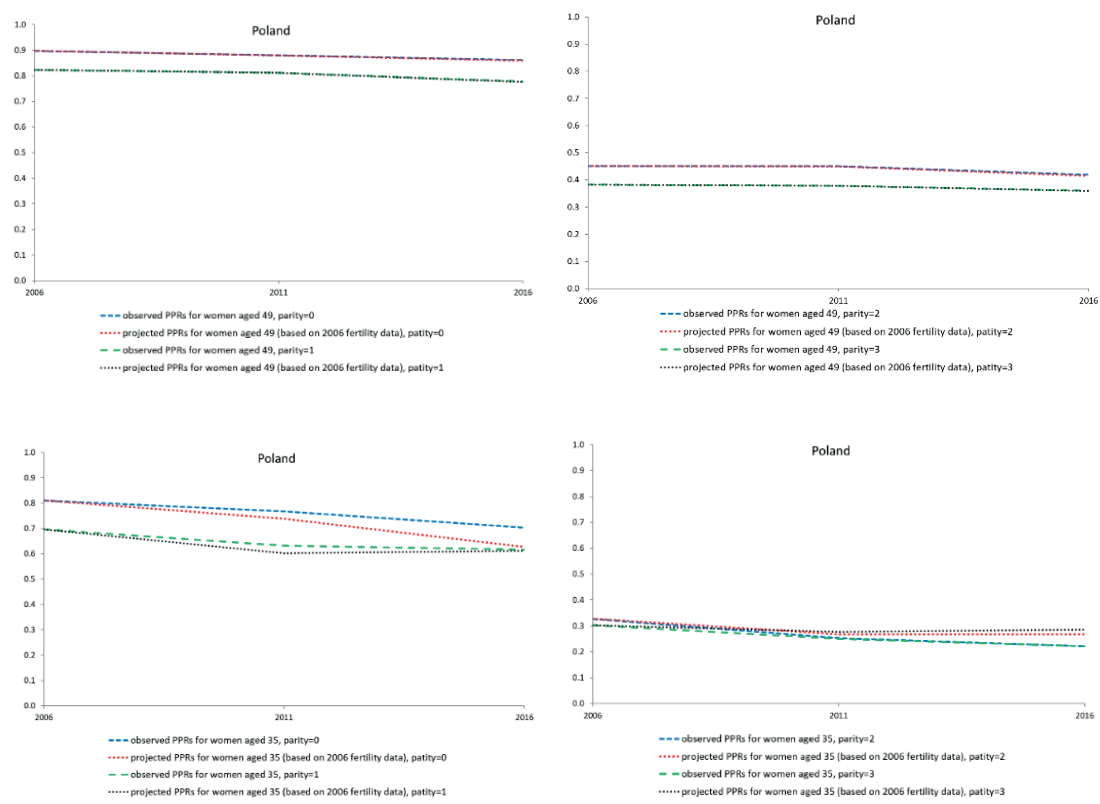

\section{Portugal}
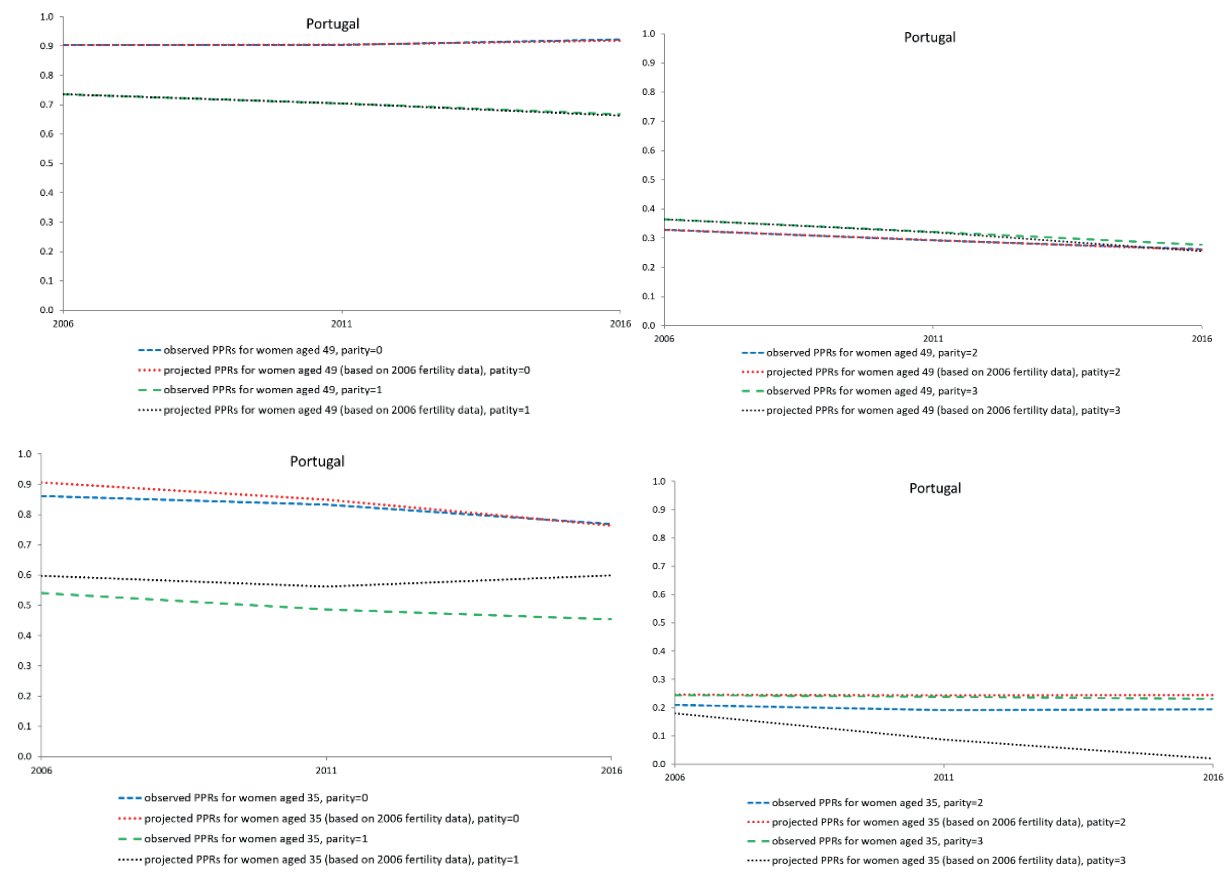


\section{Spain}
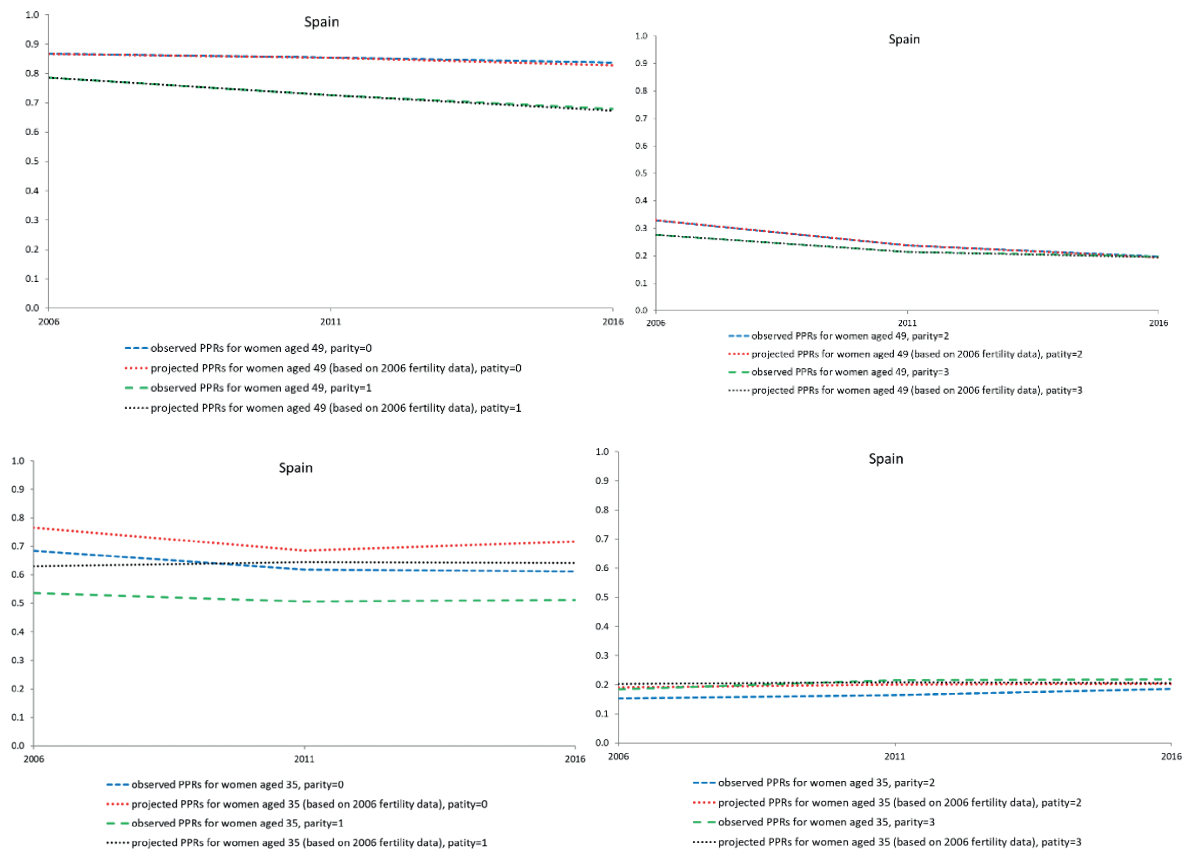

\section{Sweden}
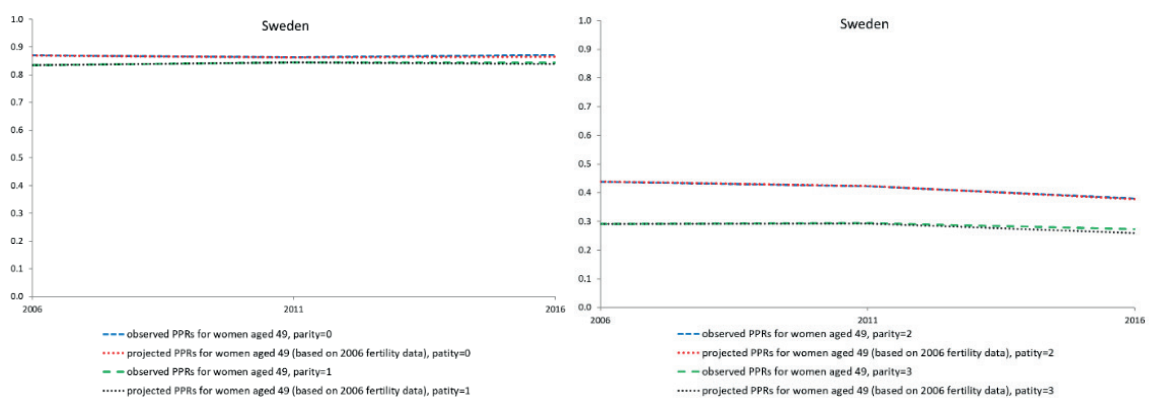

-... projected PPRs for women aged 49 (based on 2006 fertility data), patity=

- observed PPRs for women aged 49, parity=1

...... projected PPPs for women aged 49 (based on 2006 fertility data), patity=1

..... projected PPRs for wonen abed 35 (based on 2006 fertility datal patity

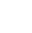



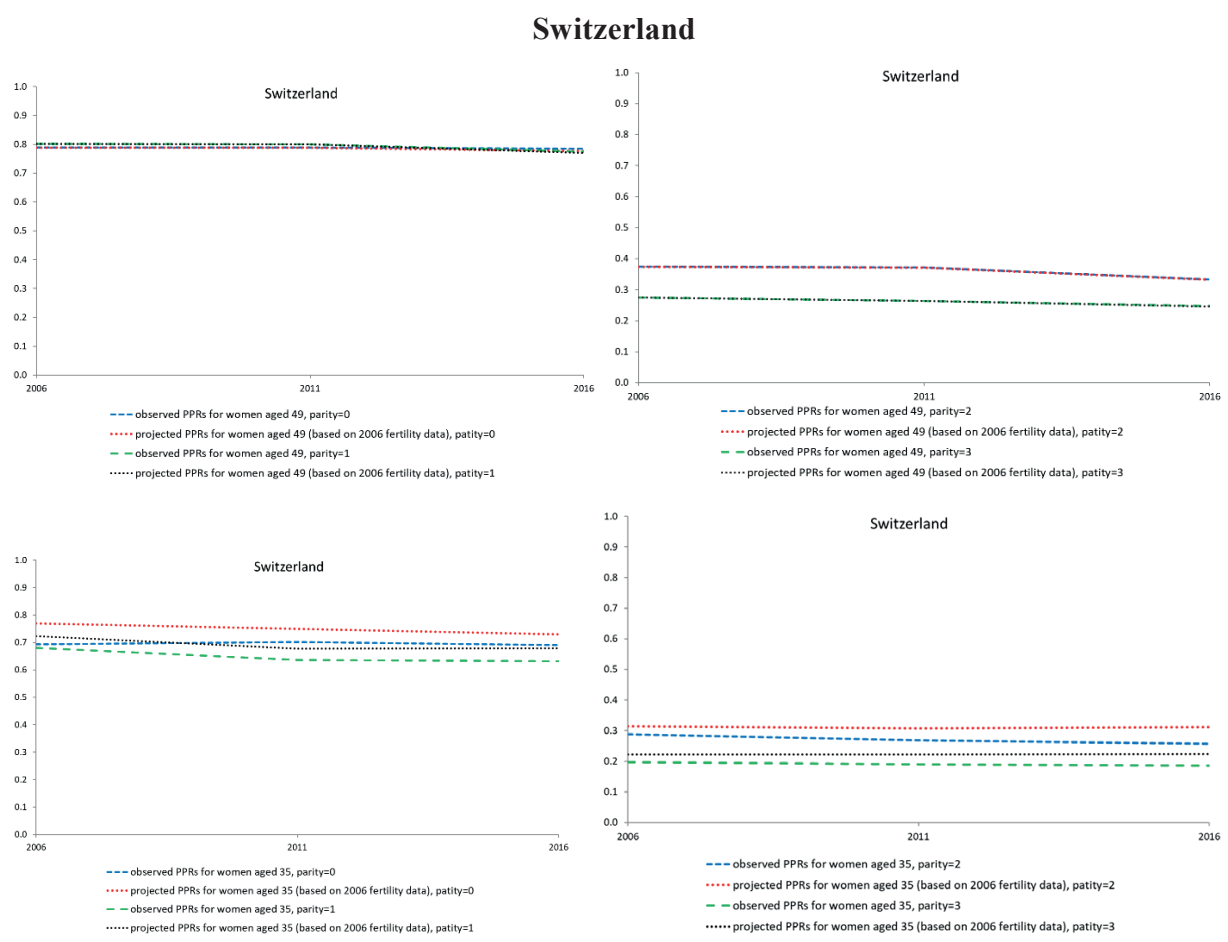

Figure 8. Projected and observed (completed) PPRs for women aged 49 and 35, parity $i=0,1,2,3$

Source: the author's own elaboration; The Human Fertility Database

It turns out that the projected PPR values are almost identical to the observed rates for women aged 49 in 2011 or 2016, correspondingly. On the other hand, comparing the projected and observed PPRs for women reaching age 35 in 2011 or 2016, respectively, we can find (cf. Figure 8) that the prognoses show some deviations for almost all the countries considered.

\section{Conclusions}

Parity progressive ratios give the probability that a woman of a given birth order ever proceeds to the next order. They have acquired a dominant place in fertility research. They have gained in importance as useful measures of fertility, especially when we want to compare the reproductive performance of two or more populations with a similar pattern of spacing but different desired family sizes.

In this work, we focused on the description and analysis of progressive fertility measures for the 2016 European female populations and we investigated the tempo and pattern of fertility in European countries. Then we used the projected 
parity progression ratio method to estimate the future trends of parity progression ratios. The objective of this study is to assess how well the projected parity progression ratio method works. Besides, traditional measures of fertility were also mentioned, age-specific fertility rates (ASFR), age-order specific fertility rates (AOSFR) and total fertility rates, which use age as the main structural feature of the female population. Based on the data from the HFD, we computed ASFR, AOSFR, PPR and PPPR for eight countries, next we presented them graphically. The results show that the projected parity progression ratio method produces a relatively good fit. In conclusion, it can be said that the PPPR method is useful in predicting the future trends of parity.

The fertility trends in the countries analysed are the result of many factors. The analysis shows that late decisions to have the first child and the tendency of women to have fewer children contribute to the fertility decline. In all countries, there is no problem with people wanting to have one child. The results indicate that most people also consider having a second child. In contrast, the situation is much worse when it comes to having further children. For example, the projected parity progression rates for Polish young women at the end of the reproductive period are expected to be about 20-40\% lower than the completed PPR recorded in 2016.

\section{References}

Aoun S., Airey P. (1988), Illustrative application of the use of projected parity progression ratios for the analysis of fertility, London School of Hygiene Tropical Medicine, Centre for Population Studies, London.

Bhardwaj S.B., Sharma G.C., Kumar A. (2010), Analysis of the Parity Progression Ratios, "Journal of Reliability and Statistical Studies", vol. 3, no. 1, pp. 37-41.

Billari F.C., Kohler H. (2004), Patterns of low and very low fertility in Europe, "Population Studies", vol. 58, no. 2, pp. 161-176.

Brass W. (1985), Advances in Methods for Estimating Fertility and Mortality from Limited and Defective Data, London School of Hygiene and Tropical Medicine, Centre for Population Studies, London.

Brass W., Juarez F. (1983), Censored cohort parity progression ratios from birth histories, "Asian Pacific Census Forum", vol. 10, no. 1, pp. 5-13.

Feeney G. (1983), Population Dynamics Based on Birth Intervals and Parity Progression, "Population Studies", vol. 37, pp. 75-89.

Feeney G., Jingyuan Y. (1987), Period parity progression measures of fertility in China, "Population Studies", vol. 41, pp. 77-102.

Frejka T. (2008), Parity distribution and completed family size in Europe Incipient decline of the two-child family model, "Demographic Research", vol. 19(14), pp. 4-72.

Henry L. (1980), Fertility of marriages: A new method of measurement, "Population Studies Translation Series", no. 3, United Nations (French Edition Published in 1953).

Islam M., Yadava C. (1997), On the estimation of parity progression ratio, "Sankhya", vol. 58, series B, pp. 200-208.

Kohler H., Billari F.C., Ortega J.A. (2002), The emergence of lowest-low fertility in Europe during the 1990s, "Population and Development Review", vol. 28(4), pp. 641-680. 
Moultrie T., Dorrington R., Hill A., Hill K., Timaus I., Zaba B. (2013), Tools for demographic estimation, International Union for the Scientific Study of Population, Paris.

Our World in Data, https://ourworldindata.org [accessed: 14.10.2020].

Preston S.H., Heuveline P., Guillot M. (2001), Demography: Measuring and Modelling Population Processes, Blackwell, Oxford.

Rodriguez G., Hobcraft J. (1980), Illustrative analysis: Life table analysis of birth intervals in Colombia, WFS Scientific Reports 16.

Rossa A., Palma A. (2020), Predicting parity progression ratios for young women by the end of their childbearing life, "Statistics in Transition New Series", vol. 21, no. 1, pp. 55-71.

Sloggett A., Brass W., Eldridge S. M., Timæus I.M. (1994), Estimation of Demographic Parameters from Census Data, Statistical Institute for Asia and the Pacific, Tokyo.

The Human Fertility Database, http://www.humanfertility.org [accessed: 14.10.2020].

Yadava R., Bhattcharya M. (1985), Estimation of parity progression ratios from closed and open birth interval data, Mimeo, Centre of Population Studies, Banaras Hindu University, Varanasi.

Yadava R., Kumar A. (2011), On the estimation of parity progression ratios, "Journal of Scientific Research", vol. 55, pp. 127-134.

Yadava R., Pandey A., Saxena N. (1992), Estimation of parity progression ratios from the truncated distribution of closed and open birth intervals, "Mathematical Biosciences", vol. 110, pp. 181-190.

\section{Trendy płodności w krajach europejskich}

Streszczenie: Analiza płodności jest w demografii tematem, który przyciąga uwagę wielu badaczy. Demografowie opracowali wiele różnych metod pomiaru tego zjawiska. Większość badań wykorzystuje tradycyjne miary. Nie dają one jednak szczegółowych informacji na temat tego, jak dokładnie zmienia się płodność w zależności od kolejności urodzenia. Głównym celem jest zbadanie tempa i wzorca płodności oraz zróżnicowania postępów w zakresie kolejności urodzeń w wybranych krajach europejskich.

Metoda zapoczątkowana przez Brassa pozwala oszacować progresywne współczynniki kolejności urodzeń. W badaniu tym dokonujemy porównań między obserwowanymi i przewidywanymi współczynnikami.

Wyniki pokazują, że metoda prognozowanych współczynników kolejności urodzeń daje stosunkowo dobre dopasowanie i jest przydatna do przewidywania przyszłych trendów płodności. Spadek dzietności w rozważanych krajach europejskich jest spowodowany późnymi decyzjami kobiet o posiadaniu pierwszego dziecka oraz ich tendencją do rodzenia mniejszej liczby dzieci.

Słowa kluczowe: płodność, współczynniki dzietności, dzietność kobiet, cząstkowe współczynniki płodności, wskaźnik przeciętnej kolejności urodzenia, progresywne współczynniki kolejności urodzenia

JEL: J11, J12, J13 


\begin{tabular}{|c|c|c|c|c|}
\hline \multirow[t]{2}{*}{ OPEN } & \multirow{2}{*}{\multicolumn{3}{|c|}{ ACCESS }} & $\begin{array}{l}\text { (c) by the author, licensee Lodz University - Lodz University Press, Łódź, Poland. } \\
\text { This article is an open access article distributed under the terms and conditions } \\
\text { of the Creative Commons Attribution license CC-BY } \\
\text { (https://creativecommons.org/licenses/by/4.0/) }\end{array}$ \\
\hline & & & & Received: 2020-12-03; verified: 2021-02-02. Accepted: 2021-04-14 \\
\hline C & $\mathbf{O}$ & \multicolumn{2}{|c|}{$\mathbf{P} \mathbf{E}$} & \multirow[t]{2}{*}{$\begin{array}{l}\text { This journal adheres to the COPE's Core Practices } \\
\text { https://publicationethics.org/core-practices }\end{array}$} \\
\hline \multicolumn{4}{|c|}{$\begin{array}{c}\text { Member since } 2018 \\
\text { JM13703 }\end{array}$} & \\
\hline
\end{tabular}

